\title{
Annexin 7 in the Regulation of Gastric Acid Secretion
}

\author{
Venkanna Pasham ${ }^{a}$ Anand Rotte ${ }^{a}$ Sobuj Mia ${ }^{a}$ Ioana Alesutan ${ }^{a}$ Soumya \\ Chatterjee $^{\mathrm{a}}$ Zohreh Hosseinzadeh $^{\mathrm{a}}$ Madhuri Bhandaru ${ }^{\mathrm{a}}$ Angelika A. Noegel ${ }^{\mathrm{b}}$ \\ Florian Lang ${ }^{a}$
}

${ }^{a}$ Department of Physiology, University of Tübingen, Tübingen, ${ }^{b}$ Center for Biochemistry, Institute of Biochemistry I, Medical Faculty, University of Cologne, Köln, Germany

\section{Key Words}

Stomach $\bullet \mathrm{H}^{+} / \mathrm{K}^{+}$ATPase $\bullet \mathrm{K}^{+}$recycling $\bullet \mathrm{H}^{+}$secretion $\bullet$ glucocorticoids

\begin{abstract}
Background/Aims: Glucocorticoids enhance gastric acid secretion and inhibit gastric cyclooxygenase, thus downregulating formation of $\mathrm{PGE}_{2^{\prime}}$ an inhibitor of gastric acid secretion. In erythrocytes, $\mathrm{PGE}_{2}$ formation is inhibited by annexin 7 . The present study thus explored whether annexin 7 participates in the regulation of gastric acid secretion. Methods: Annexin 7 protein expression was determined by Western blotting, cytosolic $\mathrm{pH}(\mathrm{pHi})$ of parietal cells utilizing BCECF-fluorescence, and gastric acid secretion by determination of $\mathrm{Na}^{+}$-independent $\mathrm{pHi}$ recovery from an ammonium pulse $(\Delta \mathrm{pHi} / \mathrm{min})$. Experiments were performed in isolated glands from gene targeted mice lacking annexin $7\left(a n x 7^{--}\right)$and in respective wild type animals $\left(a n x 7^{+/+}\right)$. Results: Prior to treatment $\mathrm{pHi}$ and $\Delta \mathrm{pHi} / \mathrm{min}$ were similar in isolated gastric glands from $a n x 7^{-/-}$and from $a n x 7^{+/+}$mice. Aspirin $(100 \mu \mathrm{M}$ added to the glands $1 \mathrm{hr}$ prior to the experiment) significantly increased $\Delta \mathrm{pHi} / \mathrm{min}$ to similar values in both genotypes. The administration of dexamethasone $(10 \mu \mathrm{g} / \mathrm{g}$ BW subcutaneously for 4 consecutive days prior to the experiments) significantly increased $\Delta \mathrm{pH} / \mathrm{min}$ in $a n x 7^{+/+}$mice but not in anx $7^{-/}$mice. Following dexamethasone treatment, the luminal $\mathrm{pH}$ was significantly lower and the acid content significantly higher in $a n x 7^{+/+}$mice than in anx $7^{-1-}$ mice. An increase of extracellular $\mathrm{K}^{+}$concentration to $35 \mathrm{mM}$ (replacing $\mathrm{Na}^{+} / \mathrm{NMDG}^{+}$) significantly increased $\Delta \mathrm{pHi} / \mathrm{min}$ in both genotypes. In neither genotype dexamethasone increased $\Delta \mathrm{pH} / \mathrm{min}$ further in the presence of $35 \mathrm{mM} \mathrm{K}^{+}$or presence of aspirin. Conclusions: Annexin 7 is required for the stimulation of gastric acid secretion by glucocorticoids.
\end{abstract}




\section{Introduction}

Annexins, $\mathrm{Ca}^{2+}$ - and phospholipid-binding intracellular proteins [1-5], contribute to the regulation of a wide variety of functions such as inhibition of phospholipase $A_{2}[6,7]$, regulation of ion channels [8], aggregation of chromaffin granules [9], endo- and exocytosis [10, 11] or crosslinking of proteins within the cell cortex [12]. The isoform annexin 7 (or annexin VII, synexin) has been shown to interfere with prostaglandin $\mathrm{E}_{2}\left(\mathrm{PGE}_{2}\right)$ formation [13] and to participate in the regulation of secretion [14-16], hormone release [17], as well as cell survival and tumor growth [18-27]. Annexin 7 contributes to spherocytosis [28], cardiac remodelling [29] and inflammatory myopathies [30].

Initially generated annexin 7 knockout mice were lethal on embryonic day 10 [31]. In a second attempt viable annexin 7 knockout mice were generated [32], suffering from disorders of cardiac excitation [32,33], enhanced glial cell proliferation [34] as well as accelerated suicidal erythrocyte death [35] associated with slightly increased osmotic erythrocyte resistance [36] and relative resistance to malaria [13]. The increased suicidal erythrocyte death and partial resistance to malaria resulted from excessive formation of $\mathrm{PGE}_{2}[13]$.

$\mathrm{PGE}_{2}$ is known to inhibit gastric acid secretion [37-39], which is accomplished by the $\mathrm{H}^{+}$/ $\mathrm{K}^{+}$ATPase pumping $\mathrm{H}^{+}$into the gastric lumen in exchange of $\mathrm{K}^{+}$[40-43]. $\mathrm{K}^{+}$recycles into the lumen through KCNQ1/KCNE K+ channels [44-46]. Genetic knockout of KCNQ1 thus abrogates gastric acid secretion [47]. The channels [48-51] and thus gastric acid secretion [41, 43, 52] are stimulated by cAMP. Gastric acid secretion is further stimulated by glucocorticoids [53], which decrease prostaglandin formation by downregulating cyclooxygenase 2 [38]. Nothing is known about the involvement of annexins in the glucocorticoid-dependent regulation of gastric acid secretion.

The present study thus explored, whether annexin 7 contributes to the regulation of gastric acid secretion. To this end, gastric acid secretion was determined in gene-targeted mice lacking functional annexin 7 and their wild type littermates.

\section{Materials and Methods}

\section{Animals}

Experiments were performed in gene-targeted mice lacking annexin 7 (anx $7 \%$ ) and in corresponding wild-type mice $\left(a n x 7^{+/+}\right)$. Generation, properties and genotyping of anx $7 \%$ mice were described earlier [32]. Sex and age-matched mice with age more than 3 months were used for the experiments. All animal experiments were conducted according to the German law for the care and use of laboratory animals and were approved by local authorities (Regierungspräsidium Tübingen).

\section{Treatments}

Mice had free access to a standard mouse diet (C1310, Altromin, Lage, Germany) and tap water. Dexamethasone was administered subcutaneously at a dose of $10 \mu \mathrm{g} / \mathrm{g} \mathrm{BW}$ for 4 consecutive days to the mice prior to the experiments. Aspirin $(100 \mu \mathrm{M})$ was added to the glands $1 \mathrm{hr}$ prior to the experiment. The substances were obtained from Sigma (Taufkirchen, Germany). The stock solutions were prepared in DMSO. Sham experiments were performed by adding DMSO or plain distilled water to the perfusing solution at a final dilution of $0.1 \%$.

\section{Western blot analysis}

After sacrificing the animals, tissues were immediately snap frozen in liquid nitrogen. Samples were lysed with ice-cold lysis buffer (Thermo Fisher Scientific) supplemented with complete protease and phosphatase inhibitor cocktail (Thermo Fisher Scientific). After centrifugation at $10000 \mathrm{rpm}$ for $5 \mathrm{~min}, 30 \mu \mathrm{g}$ protein were boiled in Roti-Load1 Buffer (Carl Roth $\mathrm{GmbH}$ ) at $100^{\circ} \mathrm{C}$ for $10 \mathrm{~min}$. Proteins were separated on SDS-polyacrylamide gels and transferred to PVDF membranes. The membranes were incubated overnight at $4^{\circ} \mathrm{C}$ with primary goat anti-Annexin 7 antibody (diluted 1:200, R\&D Systems) or rabbit anti-GAPDH antibody (diluted 1:1000, Cell Signaling) and then with secondary anti-goat HRP-conjugated antibody 
(diluted 1:2000, Santa Cruz Biotechnology) or with secondary anti-rabbit HRP-conjugated antibody (diluted 1:1000, Cell Signaling) for 1 hour at room temperature. For loading controls, the membranes were stripped in stripping buffer (Carl Roth $\mathrm{GmbH}$ ) at $56^{\circ} \mathrm{C}$ for $5 \mathrm{~min}$. Antibody binding was detected with the ECL detection reagent (Amersham). Bands were quantified with Quantity One Software (Bio-Rad Laboratories).

\section{Gastric $\mathrm{H}^{+}$secretion}

For isolation of gastric glands animals were fasted for 16 hours prior to experiments on wire grids with free access to tap water. After sacrificing the animals the stomach was removed and cut longitudinally. After washing with standard HEPES solution the fundic and pyloric regions were discarded and the gastric corpus was sliced into $0.3 \mathrm{~cm}^{2}$ sections. The tissues were transferred onto the cooled stage of a dissecting microscope and individual glands were carefully detached from the gastric wall by snapping off the tissue using sharpened microdissection tweezers. Care was taken not to touch the apical part of the glands. The glands were attached to a glass coverslip precoated with Cell-Tak adhesive (BD Biosciences) [54].

The solutions, flow lines and perfusion chamber were maintained at $37^{\circ} \mathrm{C}$ by a thermostatically controlled heating system. The volume of the perfusion chamber was $600 \mu \mathrm{l}$ and the flow rate was $4 \mathrm{ml} /$ min for all solutions. For digital imaging of cytosolic $\mathrm{pH}\left(\mathrm{pH}_{\mathrm{i}}\right)$ isolated individual glands were incubated in a HEPES-buffered Ringer solution containing $10 \mu \mathrm{M}$ BCECF-AM (Molecular Probes, Leiden, The Netherlands) for $15 \mathrm{~min}$ at $37^{\circ} \mathrm{C}$. After loading, the chamber was flushed for $5 \mathrm{~min}$ with Ringer solution to remove any deesterified dye sticking to the outside of the glands. The perfusion chamber was mounted on the stage of an inverted microscope (Zeiss Axiovert 135), which was used in the epifluorescence mode with a $40 \mathrm{x}$ oil immersion objective (Zeiss Neoplan, Germany). BCECF was successively excited at 490/10 and 440/10 nm and the resultant fluorescent signal was monitored at 535/10 nm using an intensified charge-coupled device camera (Proxitronic, Germany) and specialized computer software (Metafluor, USA) [55]. Between 8 and 20 parietal cells were outlined and monitored during the course of the measurements. The results from each cell were averaged and taken for final analysis. Intensity ratio (490/440) data were converted into $\mathrm{pH}$ values using the high- $\mathrm{K}^{+} /$nigericin calibration technique $[56,57]$. To this end the glands were perfused at the end of each experiment for 5 minutes with standard high- $\mathrm{K}^{+} /$nigericin $(10 \mu \mathrm{g} / \mathrm{ml})$ solution $(\mathrm{pH} 7.0)$. The intensity ratio data thus obtained were converted into $\mathrm{pH}$ values using the $\mathrm{r}_{\max }, \mathrm{r}_{\min }, \mathrm{pK}_{\mathrm{a}}$ values previously generated from calibration experiments performed in isolated gastric glands to generate a standard nonlinear curve ( $\mathrm{pH}$ range 5 to 8.5 ). The intensity ratio data were converted into $\mathrm{pH}$ values using the following equation:

$\mathrm{pH}=\mathrm{pK}_{\mathrm{a}}\left[\log \left(\left(\right.\right.\right.$ ratio $_{\text {test }} /$ ratio $\left.\left._{\mathrm{pH} 7.0}\right)-\mathrm{r}_{\min }\right) /\left(\mathrm{r}_{\max }-\left(\right.\right.$ ratio $_{\text {test }} /$ ratio $\left.\left.\left._{\mathrm{pH} 7.0}\right)\right)\right]$.

For acid loading, cells were transiently exposed to a solution containing $20 \mathrm{mM} \mathrm{NH}_{4} \mathrm{Cl}$ leading to marked initial alkalinization of cytosolic $\mathrm{pH}\left(\mathrm{pH}_{\mathrm{i}}\right)$ due to entry of $\mathrm{NH}_{3}$ and binding of $\mathrm{H}^{+}$to form $\mathrm{NH}_{4}^{+}[58,59]$. The acidification of cytosolic $\mathrm{pH}$ upon removal of ammonia allowed calculating the mean intrinsic buffering power (ß) of the cells [58]. Assuming that $\mathrm{NH}_{4}{ }^{+}$and $\mathrm{NH}_{3}$ are in equilibrium in cytosolic and extracellular fluid and that ammonia leaves the cells as $\mathrm{NH}_{3}$ :

$ß=\Delta\left[\mathrm{NH}_{4}^{+}\right]_{\mathrm{i}} / \Delta \mathrm{pH}_{\mathrm{i}}$,

where $\Delta \mathrm{pH}_{\mathrm{i}}$ is the decrease of cytosolic $\mathrm{pH}\left(\mathrm{pH}_{\mathrm{i}}\right)$ following ammonia removal and $\Delta\left[\mathrm{NH}_{4}^{+}\right]_{\mathrm{i}}$ is the decrease of cytosolic $\mathrm{NH}_{4}{ }^{+}$concentration, which is identical to the concentration of $\left[\mathrm{NH}_{4}{ }^{+}\right]_{\mathrm{i}}$ immediately before the removal of ammonia. The $\mathrm{pK}$ for $\mathrm{NH}_{4}^{+} / \mathrm{NH}_{3}$ is 8.9 [60] and at an extracellular $\mathrm{pH}\left(\mathrm{pH}_{0}\right)$ of 7.4 the $\mathrm{NH}_{4}{ }^{+}$concentration in extracellular fluid $\left(\left[\mathrm{NH}_{4}{ }^{+}\right]_{0}\right)$ is $19.37\left[20 /\left(1+10^{\mathrm{pHo}-\mathrm{pK}}\right)\right] \mathrm{mM}$. The intracellular $\mathrm{NH}_{4}{ }^{+}$ concentration $\left(\left[\mathrm{NH}_{4}\right]_{\mathrm{i}}\right)$ was calculated from:

$\left[\mathrm{NH}_{4}\right]_{\mathrm{i}}=19.37 \cdot 10^{\mathrm{pHo}-\mathrm{pHi}} \mathrm{mM}$.

The calculation of the buffer capacity required that $\mathrm{NH}_{4}^{+}$exits completely. After the initial decline, $\mathrm{pH}_{\mathrm{i}}$ indeed showed little further change in the absence of $\mathrm{Na}^{+}$and presence of omeprazole, indicating that there was no relevant further exit of $\mathrm{NH}_{4}^{+}$. The $\mathrm{pH}$ recovery during and following the $\mathrm{NH}_{4}^{+}$pulse was determined in the absence of $\mathrm{Na}^{+}$to prevent cellular realkalinization by the $\mathrm{Na}^{+} / \mathrm{H}^{+}$exchanger.

To calculate the $\Delta \mathrm{pH} / \mathrm{min}$ during re-alkalinization, a manual linear fit was placed over a narrow $\mathrm{pH}$ range ( $\mathrm{pH} 6.7$ to 6.9) which could be applied to all measured cells [61]. The solutions were composed of (in mM): standard HEPES: $115 \mathrm{NaCl}, 5 \mathrm{KCl}, 1 \mathrm{CaCl}_{2}, 1.2 \mathrm{MgSO}_{4}, 2 \mathrm{NaH}_{2} \mathrm{PO}_{4} 10$ glucose, 32.2 HEPES; sodium free HEPES: $132.8 \mathrm{NMDG}^{+} \mathrm{Cl}, 3 \mathrm{KCl}, 1 \mathrm{CaCl}_{2}, 1.2 \mathrm{MgSO}_{4}, 2 \mathrm{KH}_{2} \mathrm{PO}_{4}, 32.2 \mathrm{HEPES}, 10$ mannitol, 10 glucose (for sodium free ammonium chloride $10 \mathrm{mM} \mathrm{NMDG}^{+} \mathrm{Cl}^{-}$and mannitol were replaced with $20 \mathrm{mM} \mathrm{NH}_{4} \mathrm{Cl}$ ); high $\mathrm{K}^{+}$for calibration: $105 \mathrm{KCl}, 1 \mathrm{CaCl}_{2}, 1.2 \mathrm{MgSO}_{4}, 32.2 \mathrm{HEPES}, 10$ mannitol, $10 \mu \mathrm{g} / \mathrm{ml}$ nigericin. The $\mathrm{pH}$ of the 
solutions was titrated to 7.4 or 7.0 with $\mathrm{HCl} / \mathrm{NaOH}, \mathrm{HCl} / \mathrm{NMDG}$ and $\mathrm{HCl} / \mathrm{KOH}$, respectively, at $37^{\circ} \mathrm{C}$. Where indicated, the $\mathrm{K}^{+}$concentration was increased at the expense of $\mathrm{Na}^{+} / \mathrm{NMDG}^{+}$to $35 \mathrm{mM}$.

\section{Determination of $p H$ and acid content of the gastric lumen}

The $\mathrm{pH}$ of the luminal stomach contents depends on the amount of acid secreted. Activation of gastric gland leads to decrease in luminal $\mathrm{pH}$ and conversely inhibition leads to increase in $\mathrm{pH}$. The luminal $\mathrm{pH}$ of the overnight fasted mice serves therefore as a useful indicator of basal gastric acid secretion. To determine the basal intraluminal pH, a previously described method was slightly modified and used [62-64]. Briefly, the mice were fasted overnight on wire grids with free access to tap water and sacrificed under slight ether anaesthesia. The whole stomach was then carefully removed and cut open and the luminal contents were collected by washing the stomach with $10 \mathrm{ml}$ unbuffered isotonic sodium chloride solution (containing additionally $5 \mathrm{mM} \mathrm{KCl}$ and $10 \mathrm{mM}$ glucose). The washings were then centrifuged at $150 \mathrm{~g}$ for 5 minutes to remove the particulate matter and the $\mathrm{pH}$ of the supernatant solution was measured by a standard $\mathrm{pH}$ meter (Knick, Germany). The acid content in the solution was measured by titration of the above obtained supernatant solution with $0.01 \mathrm{~N} \mathrm{NaOH}$ to an endpoint of $\mathrm{pH} 7.0$ by monitoring the $\mathrm{pH}$ with a pH meter and additionally adding a universal $\mathrm{pH}$ indicator (Sigma, Taufkirchen, Germany) to the solution. The acid content thus obtained was then corrected by the acid content of the blank isotonic sodium chloride solution and used for further statistical analysis.

\section{Statistics}

Intracellular $\mathrm{pH}, \mathrm{pH}$ recovery and buffer capacity of all parietal cells from one gland were averaged and the respective mean values were used for further statistical analysis. Data are provided as arithmetic means \pm SEM, $n$ represents the number of mice used. All data were tested for significance using Student's t-test with Welch's correction or ANOVA (Dunnets test), where applicable, and only results with $p<0.05$ were considered statistically significant.

\section{Results}

The present paper pursued the hypothesis that annexin 7 participates in the regulation of gastric acid secretion by glucocorticoids, such as dexamethasone. To possibly disclose a role of annexin 7 in the regulation of gastric acid secretion, annexin 7 knockout (anx $\%$ ) mice and corresponding wild-type animals $\left(a n x 7^{+/+}\right)$were analysed. Following an overnight fasting period the body weight and the weight of empty stomach were determined. The body weight was similar in $a n x 7 \%$ mice $(20.5 \pm 1.8 \mathrm{~g}, \mathrm{n}=5)$ and $a n x 7^{+/+}$mice $(23.6 \pm 1.6 \mathrm{~g}, \mathrm{n}=5)$. The stomach weight was again similar in anx $\%$ mice $(0.27 \pm 0.02 \mathrm{~g}, \mathrm{n}=5)$ and $a n x 7^{+/+}$mice $(0.24 \pm 0.01 \mathrm{~g}, \mathrm{n}=5)$. Western blot analysis was performed in gastric tissue from anx $7 \%$ and an $x 7^{+/+}$mice without treatment or following prior treatment with dexamethasone $(10 \mu \mathrm{g} / \mathrm{g}$ BW for 4 consecutive days prior to the experiments) to elucidate the expression of annexin 7. As illustrated in Fig. 1, annexin 7 is expressed in parietal cells from $a n x 7^{+/+}$mice but not from $a n x 7 \%$ mice. Dexamethasone treatment did not appreciably alter annexin 7 expression in neither anx $7 \%$ nor $a n x 7^{+/+}$mice. Thus, annexin 7 is expressed in gastric glands but its expression is not modified by glucocorticoids.

The impact of annexin 7 on gastric acid secretion was explored by utilizing BCECF fluorescence for the determination of cytosolic $\mathrm{pH}$. Without treatment cytosolic $\mathrm{pH}$ was similar in isolated gastric glands from anx $7 \%$ and from $a n x 7^{+/+}$mice. Cytosolic $\mathrm{pH}$ was not significantly modified by treatment with dexamethasone $(10 \mu \mathrm{g} / \mathrm{g}$ BW for 4 consecutive days to the mice prior to the experiments) or aspirin $(100 \mu \mathrm{M}$ added to the glands $1 \mathrm{hr}$ prior to the experiment) or by increasing extracellular $\mathrm{K}^{+}$concentration from $5 \mathrm{mM}$ to $35 \mathrm{mM}$ (Table 1). The buffer capacity was also not significantly different between gastric gland cells from anx 7 1 - and $a n x 7^{+/+}$mice and was again not significantly different between presence or absence of dexamethasone, aspirin or enhanced extracellular $\mathrm{K}^{+}$concentration (Table 1). Accordingly, the effect of $\mathrm{H}^{+}$movement across the cell membrane is reflected by the respective changes of cytosolic $\mathrm{pH}$ in gastric glands from $a n x 7 \%$ and $a n x 7^{+/+}$mice. Gastric $\mathrm{H}^{+} / \mathrm{K}^{+}$ATPase activity 
Fig. 1. Expression of annexin 7 in gastric tissue. A. Original Western blot of the expression of annexin 7 protein in the gastric tissue from anx $7^{\%-}$ mice and $a n x 7^{+/+}$mice without treatment or following treatment with dexamethasone $(10 \mu \mathrm{g} / \mathrm{g}$ BW for 4 consecutive days to the experiments). B. Arithmetic means \pm SEM ( $n=4$ mice each group, a.u.) of the relative expression of annexin 7 protein in the gastric tissue from an $x 7^{-/}$mice (black bars) and $a n x 7^{+/+}$mice (white bars) without treatment or following prior treatment with dexamethasone $(10 \mu \mathrm{g} / \mathrm{g}$ BW for 4 consecutive days prior to the experiments).

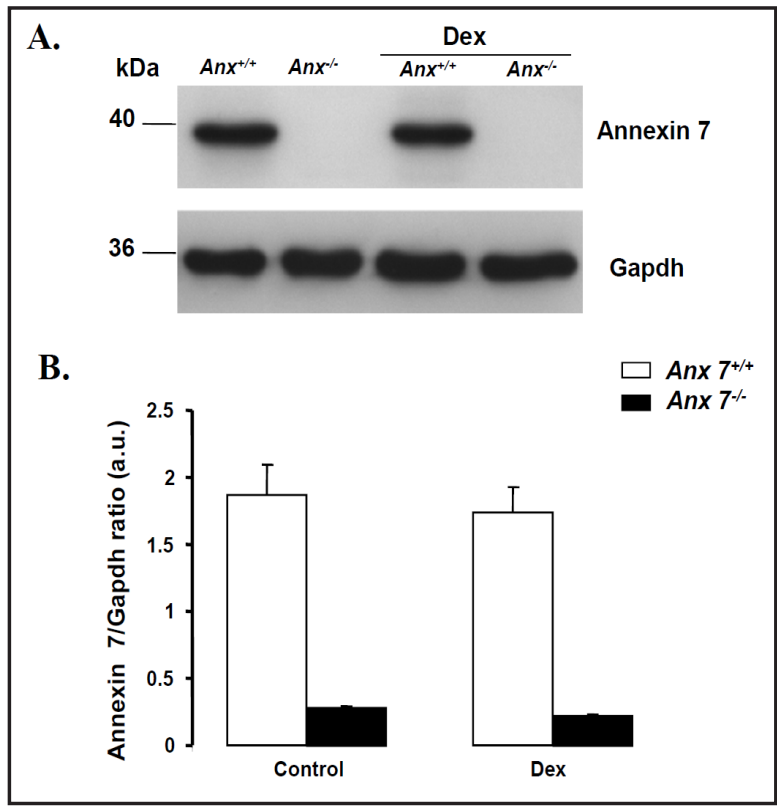

Table 1. Gastric acid secretion in $a n x 7^{\%}$ mice and $a n x 7^{+/+}$mice without treatment (Control) or following treatment with dexamethasone $(10 \mu \mathrm{g} / \mathrm{g}$ BW for 4 consecutive days prior to the experiments) or aspirin (100 $\mu \mathrm{M}$ added to the glands $1 \mathrm{hr}$ prior to the experiment) or both. Effect of an increase of bath $\mathrm{K}^{+}$concentration from $5 \mathrm{mM}$ to $35 \mathrm{mM}$. * - indicates significant difference to respective wild type mice. \# - indicates significant difference to respective control (untreated or $0.1 \%$ DMSO treated mice). $\S$ - indicates significant difference to presence and absence of aspirin during dexamethasone treatment

\begin{tabular}{|c|c|c|c|c|c|c|}
\hline $\begin{array}{l}\text { Experimental } \\
\text { condition }\end{array}$ & $\begin{array}{l}\text { Mouse } \\
\text { genotye }\end{array}$ & $\begin{array}{c}\text { Rate of } \mathrm{pH} \\
\text { recovery (delta } \\
\mathrm{pH} \text { units/minute) }\end{array}$ & $\begin{array}{l}\text { Intracellular } \\
\text { pH (units) }\end{array}$ & $\begin{array}{c}\text { Buffer } \\
\text { capacity (mM / } \\
\text { pH unit) }\end{array}$ & $\begin{array}{l}\text { Number } \\
\text { of mice }\end{array}$ & $\begin{array}{l}\text { Number } \\
\text { of cells }\end{array}$ \\
\hline \multirow[t]{2}{*}{ Control } & $\operatorname{an} x 7^{+/+}$ & $0.044 \pm 0.011$ & $7.20 \pm 0.04$ & $34.8 \pm 5.0$ & 10 & 100 \\
\hline & $\operatorname{an} x 7^{-/-}$ & $0.045 \pm 0.010$ & $7.21 \pm 0.07$ & $28.4 \pm 4.1$ & 12 & 138 \\
\hline \multirow[t]{2}{*}{ Aspirin } & $\operatorname{an} x 7^{+/+}$ & $0.123 \pm 0.015^{\#}$ & $7.25 \pm 0.05$ & $31.3 \pm 7.9$ & 6 & 60 \\
\hline & $\operatorname{an} x 7^{-/-}$ & $0.128 \pm 0.023^{\#}$ & $7.29 \pm 0.03$ & $23.0 \pm 2.4$ & 6 & 61 \\
\hline \multirow[t]{2}{*}{ Omeprazole } & $\operatorname{an} x 7^{+/+}$ & $0.003 \pm 0.014$ & $7.31 \pm 0.08$ & $17.9 \pm 3.3$ & 4 & 65 \\
\hline & $\operatorname{an} x 7^{-/-}$ & $0.002 \pm 0.011$ & $7.26 \pm 0.07$ & $17.8 \pm 4.2$ & 4 & 68 \\
\hline \multirow[t]{2}{*}{ Dexamethasone } & $\operatorname{an} x 7^{+/+}$ & $0.130 \pm 0.032$ & $7.22 \pm 0.05$ & $35.8 \pm 7.4$ & 6 & 82 \\
\hline & $\operatorname{an} x 7^{-/-}$ & $0.049 \pm 0.008^{*}$ & $7.20 \pm 0.03$ & $30.9 \pm 4.0$ & 6 & 70 \\
\hline Dexamethasone + & an $x 7^{+/+}$ & $0.123 \pm 0.020^{\#}$ & $7.14 \pm 0.02$ & $41.2 \pm 5.6$ & 6 & 53 \\
\hline Aspirin & $\operatorname{an} x 7^{-/-}$ & $0.114 \pm 0.016^{\# \S}$ & $7.20 \pm 0.03$ & $27.8 \pm 5.2$ & 6 & 44 \\
\hline \multirow[t]{2}{*}{$35 \mathrm{mM} \mathrm{K}^{+}$} & an $x 7^{+/+}$ & $0.255 \pm 0.041^{\#}$ & $7.32 \pm 0.06^{\#}$ & $31.9 \pm 6.2$ & 6 & 76 \\
\hline & $\operatorname{an} x 7^{-/-}$ & $0.233 \pm 0.016^{\#}$ & $7.30 \pm 0.05^{\#}$ & $22.7 \pm 2.9$ & 6 & 83 \\
\hline Dexamethasone + & $\operatorname{an} x 7^{+/+}$ & $0.284 \pm 0.059^{\#}$ & $7.28 \pm 0.02$ & $32.6 \pm 3.3$ & 6 & 92 \\
\hline $35 \mathrm{mM} \mathrm{K}^{+}$ & $\operatorname{an} x 7^{-1}$ & $0.275 \pm 0.032^{\#}$ & $7.30 \pm 0.03^{* \#}$ & $23.6 \pm 4.1$ & 6 & 99 \\
\hline
\end{tabular}

was estimated from the $\mathrm{Na}^{+}$-independent $\mathrm{pH}$ recovery following an ammonium pulse $\left(\Delta \mathrm{pH}_{\mathrm{i}} /\right.$ $\mathrm{min}$ ). As shown in Fig. 2, $\Delta \mathrm{pH}_{\mathrm{i}} / \mathrm{min}$ in untreated gastric glands was not significantly different between $a n x 7 \%$ and $a n x 7^{+/+}$mice. Aspirin increased $\Delta \mathrm{pH}_{\mathrm{i}} /$ min in both anx $7 \%$ and $a n x 7^{+/+}$mice. The administration of omeprazole $(100 \mu \mathrm{M})$ virtually abolished $\Delta \mathrm{pH}_{\mathrm{i}} / \mathrm{min}$ in both genotypes (Fig. 2) indicating that the observed alkalinization was due to $\mathrm{H}^{+} / \mathrm{K}^{+}$ATPase activity. The observations suggest that in the absence of glucocorticoid treatment $\mathrm{H}^{+} / \mathrm{K}^{+}$ATPase activity is downregulated by cyclooxygenase irrespective of the presence of annexin 7 .

As shown in Fig. 3, treatment with dexamethasone $(10 \mu \mathrm{g} / \mathrm{g}$ BW for 4 consecutive days prior to the experiments) increased $\Delta \mathrm{pH}_{\mathrm{i}} /$ min significantly in $a n x 7^{+/+}$mice but not in 
Fig. 2. $\mathrm{pH}$ recovery in parietal cells in the absence and presence of aspirin. Alterations of cytosolic $\mathrm{pH}\left(\Delta \mathrm{pH}_{\mathrm{i}}\right)$ in parietal cells following an ammonium pulse. To load the cells with $\mathrm{H}^{+}, 20 \mathrm{mM} \mathrm{NH}_{4} \mathrm{Cl}$ was added and $\mathrm{Na}^{+}$ removed (replaced by $\mathrm{NMDG}^{+}$, ' 0 ' $\mathrm{Na}^{+}$) in a first step (see bars below each original tracing), $\mathrm{NH}_{4} \mathrm{Cl}$ removed in a second step, $\mathrm{Na}^{+}$ added in a third step and nigericin $\left(\mathrm{pH}_{0}\right.$ '7') applied in a fourth step to calibrate each individual experiment. A. Time dependent alterations of $\mathrm{pH}_{\mathrm{i}}$ (arithmetic means \pm SEM of 6-10 cells each) in representative single experiments in $a n x 7^{+/+}$ mice (left panels) and anx $7 \%$ mice

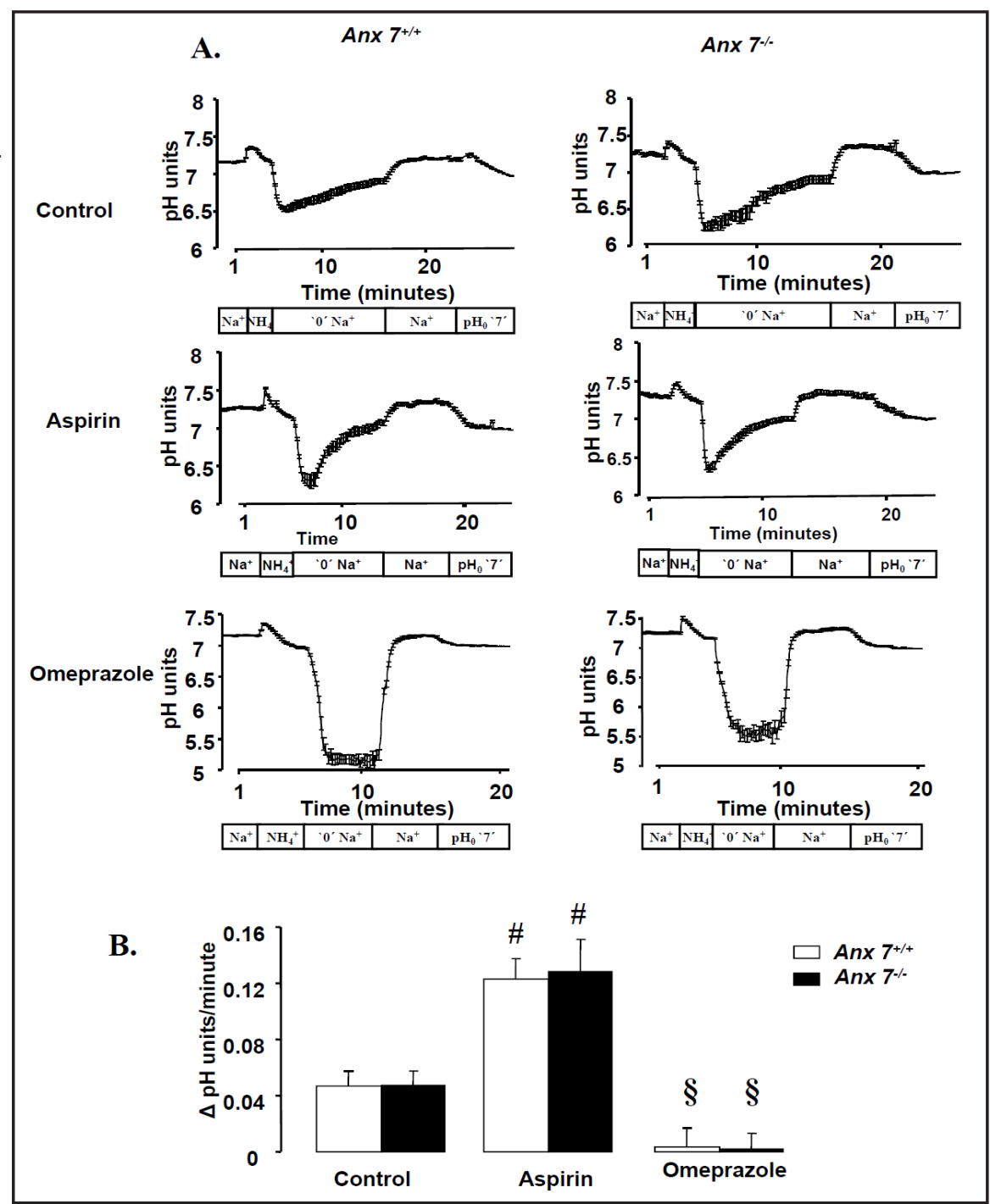

(right panels) without (upper panels) or with (middle panels) aspirin treatment (100 $\mu \mathrm{M}$ added to the glands $1 \mathrm{hr}$ prior to the experiment) or in the presence of $100 \mu \mathrm{M}$ omeprazole (lower panels). B. Arithmetic means \pm SEM ( $\mathrm{n}=4-6$ mice each group) of $\mathrm{Na}^{+}$-independent alterations of cytosolic $\mathrm{pH}\left(\Delta \mathrm{pH}_{\mathrm{i}} / \mathrm{min}\right)$ in parietal cells from anx $7^{-/}$mice (black bars) and $a n x 7^{+/+}$mice (white bars) without (left bars) and with (middle bars) aspirin treatment ( $100 \mu \mathrm{M}$ added to the glands $1 \mathrm{hr}$ prior to the experiment) or in the presence of 100 $\mu \mathrm{M}$ omeprazole (right bars). \# indicates significant difference from absence of aspirin. § indicates significant difference from absence of omeprazole.

anx $7 \%$ mice. Additional experiments were performed following exposure of gastric glands to increased extracellular $\mathrm{K}^{+}$concentration. An increase of the bath $\mathrm{K}^{+}$concentration to $35 \mathrm{mM}$ (replacing $\mathrm{Na}^{+} / \mathrm{NMDG}^{+}$) increased $\Delta \mathrm{pH} / \mathrm{min}$ to similarly high levels in $a n x 7^{+/+}$mice and in anx $7 \%$ mice (Fig. 3). In neither genotype dexamethasone treatment increased $\Delta \mathrm{pH}_{\mathrm{i}} / \mathrm{min}$ further in the presence of $35 \mathrm{mM} \mathrm{K}^{+}$. Accordingly, an increase of extracellular $\mathrm{K}^{+}$concentration abolished the stimulation of gastric acid secretion by dexamethasone treatment. The observations indicate that in the absence of annexin 7 , the stimulating effect of glucocorticoids on gastric acid secretion is virtually abrogated, an effect apparently involving $\mathrm{K}^{+}$channels.

Further experiments were performed under inhibition of cyclooxygenase by aspirin. The additional treatment of dexamethasone gastric glands with aspirin did not significantly 
Fig. 3. Effects of dexamethasone on $\mathrm{pH}$ recovery in parietal cells at normal and enhanced extracellular $\mathrm{K}^{+}$ concentration. A. Time dependent alterations of $\mathrm{pH}_{\mathrm{i}}$ (arithmetic means \pm SEM of 6-10 cells each) in representative single experiments in an $x 7^{+/+}$mice (left panels) and anx $\%$ mice (right panels) without (upper panels) and with stimulation with dexamethasone (10 $\mu \mathrm{g} / \mathrm{g}$ BW for 4 consecutive days prior to the experiments) at $5 \mathrm{mM}$ $\mathrm{K}^{+}$(middle panels) and at $35 \mathrm{mM} \mathrm{K}^{+}$(lower panels). B. Arithmetic means \pm SEM ( $\mathrm{n}=5-6$ mice each group) of $\mathrm{Na}^{+}$-independent alterations of cytosolic $\mathrm{pH}\left(\Delta \mathrm{pH}_{\mathrm{i}} /\right.$ min) in parietal cells from anx $7 \%$ mice (black bars) and $a n x 7^{+/+}$mice (white bars) at $5 \mathrm{mM}$ $\mathrm{K}^{+}$(left and middle left bars) and at $35 \mathrm{mM} \mathrm{K}^{+}$ (right and middle right
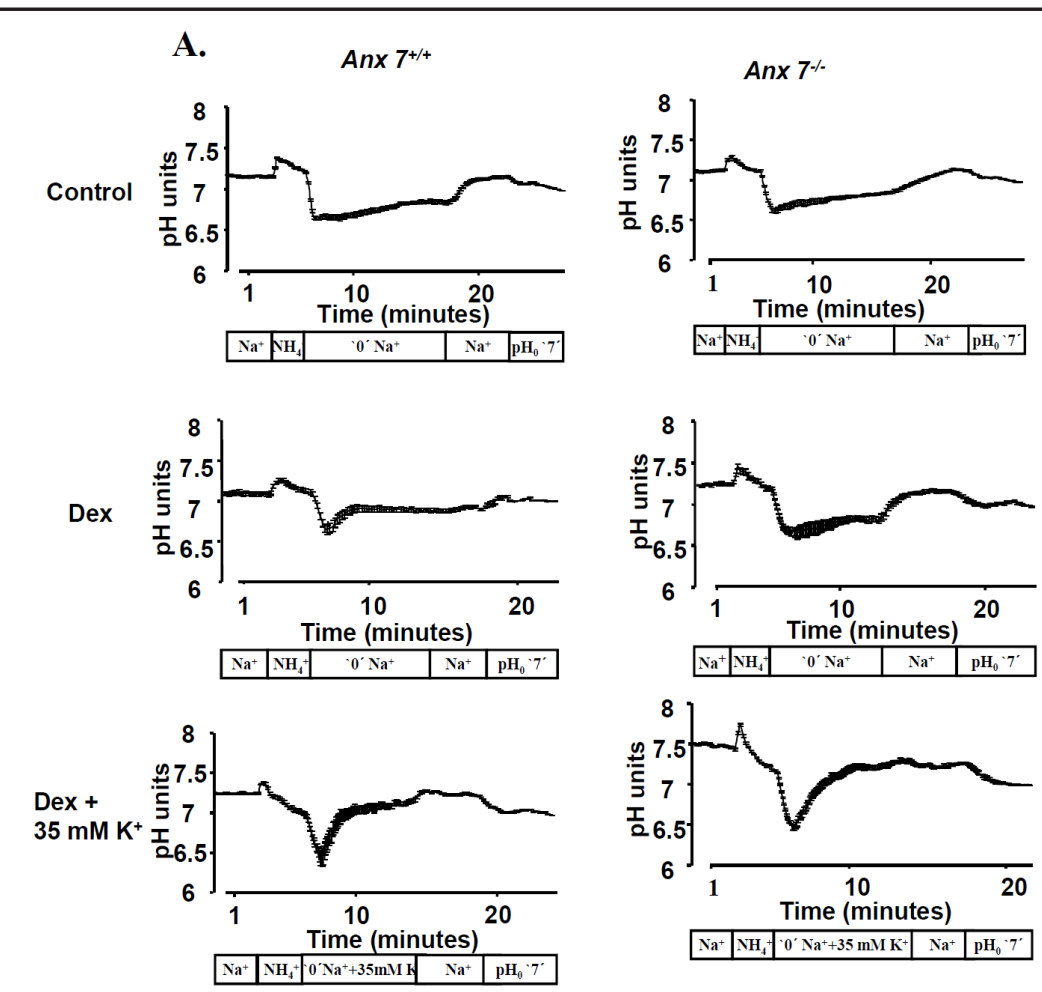

B.

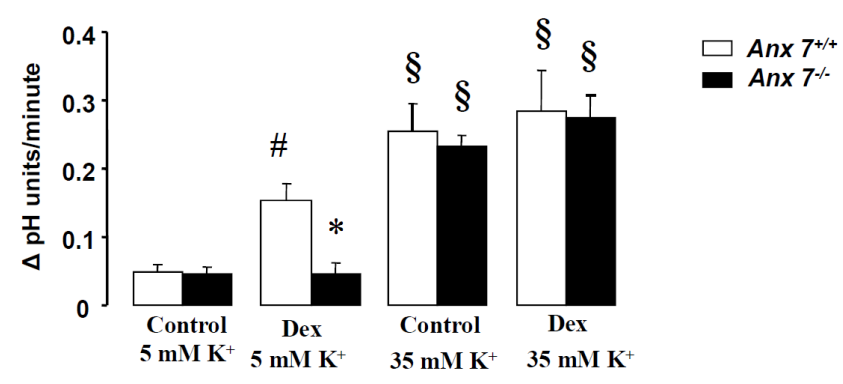

bars) without (left and middle left bars) or with dexamethasone treatment (right and middle right bars). * indicates significant difference between anx $7 \%$ mice and $a n x 7^{+/+}$mice, \# indicates significant difference to absence of dexamethasone, $\S$ indicates significant difference to $5 \mathrm{mM} \mathrm{K}^{+}$.

modify $\Delta \mathrm{pH}_{\mathrm{i}} / \min$ in $a n x 7^{+/+}$mice but significantly increased $\Delta \mathrm{pH}_{\mathrm{i}} / \mathrm{min}$ in anx $7 \%$ mice (Fig. 4). Accordingly, following treatment with both, dexamethasone and aspirin, $\Delta \mathrm{pH}_{\mathrm{i}} / \mathrm{min}$ was similarly high in $a n x 7 \%$ and $a n x 7^{+/+}$mice. Those experiments suggest that annexin 7 is effective by inhibiting cyclooxygenase.

The difference in gastric acid secretion between anx $7 \%$ mice and $a n x 7^{+/+}$mice was further studied by determination of $\mathrm{pH}$ and acid content of the gastric lumen. As shown in Fig. 5 , without treatment the $\mathrm{pH}$ of the solution containing the luminal aspirates was similar in both genotypes. Dexamethasone treatment decreased the $\mathrm{pH}$ in $a n x 7^{+/+}$mice but not in anx $7 \%$ mice. Accordingly, luminal $\mathrm{pH}$ was, following dexamethasone treatment, significantly lower in $a n x 7^{+/+}$ mice than in anx $7 \%$ mice. Similarly, the acid content was significantly higher in the gastric lumen of $a n x 7^{+/+}$mice than of $a n x 7 \%$ mice. Thus, the effects of dexamethasone and annexin 7 on $\mathrm{H}^{+}$secretion are reflected by respective alterations of luminal $\mathrm{pH}$ and acid content. 
Fig. 4. Effects of dexamethasone on $\mathrm{pH}$ recovery in parietal cells in the absence and presence of aspirin. A. Time dependent alterations of $\mathrm{pH}_{\mathrm{i}}$ (arithmetic means \pm SEM of 6-10 cells each) in representative single experiments in $a n x 7^{+/+}$ mice (left panels) and anx $\%$ mice (right panels) without (upper panels) and with stimulation with dexamethasone $(10 \mu \mathrm{g} / \mathrm{g}$ BW for 4 consecutive days prior to the experiments) without (middle panels) and with (lower panels) additional treatment with aspirin $(100 \mu \mathrm{M}$ added to the glands 1 hr prior to the experiment). B. Arithmetic means \pm SEM ( $n=6$ mice each group) of $\mathrm{Na}^{+}$-independent alterations of cytosolic $\mathrm{pH}\left(\Delta \mathrm{pH}_{\mathrm{i}} / \mathrm{min}\right)$ in parietal cells from anx $7 \%$ mice (black bars) and an $x 7^{+/+}$mice (white
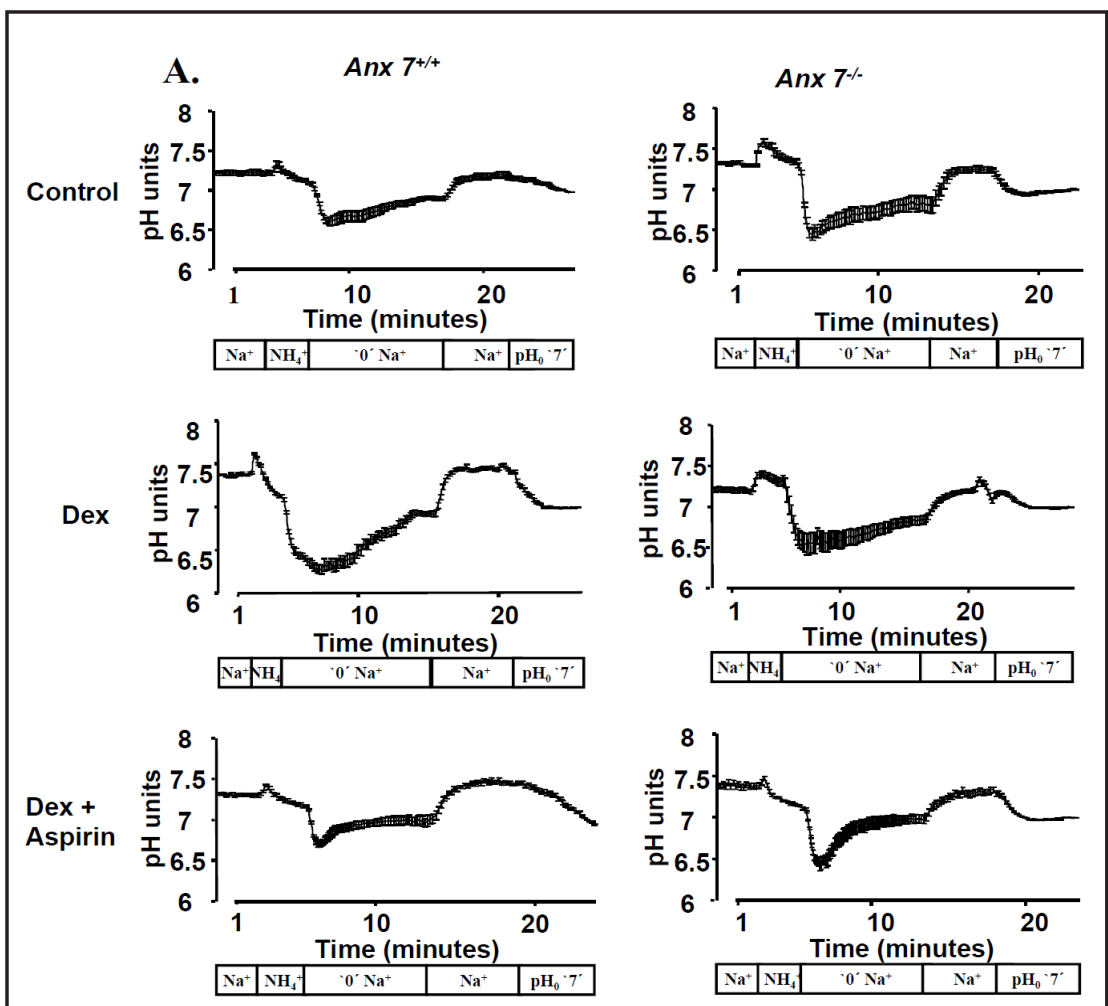

B.
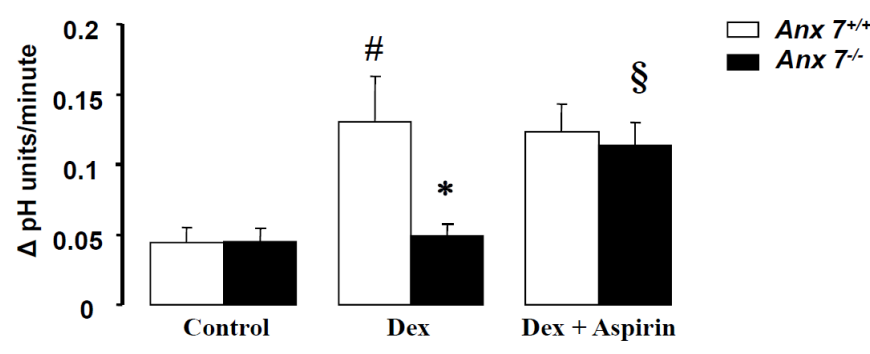

bars) in the absence of dexamethasone (left bars) or presence dexamethasone in the absence (middle bars) and presence (right bars) of aspirin. * indicates significant difference between anx $7 \%$ mice and anx $7^{+/+}$mice, \# indicates significant difference to absence of dexamethasone, $\S$ indicates significant difference to absence of aspirin.

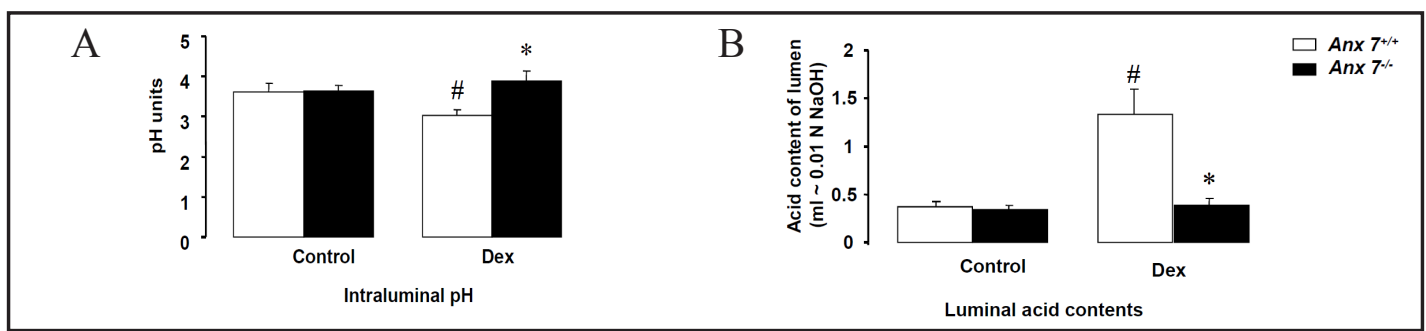

Fig. 5. Intraluminal $\mathrm{pH}$ and acid content of stomach from overnight fasted mice. Arithmetic means \pm SEM of ( $\mathrm{n}=5-7$ mice each group) of (A) the $\mathrm{pH}$ of the luminal contents and (B) acid equivalents in the luminal contents of stomach from anx $7 \%$ mice (black bars) and anx $7^{+/+}$mice (white bars) without (left bars) and with (right bars) dexamethasone treatment $(10 \mu \mathrm{g} / \mathrm{g}$ BW for 4 consecutive days to the mice prior to the experiments). * indicates significant difference between $a n x 7^{\%}$ mice and $a n x 7^{+/+}$mice. \# indicates significant difference to absence of dexamethasone. 


\section{Discussion}

The present study discloses a novel signaling molecule participating in the regulation of gastric acid secretion. Lack of annexin 7 virtually abolishes the effect of the glucocorticoid dexamethasone on gastric acid secretion, an effect reversed in the presence of cyclooxygenase inhibitor aspirin. The observations suggest that the stimulation of gastric acid secretion by glucocorticoids requires suppression of cyclooxygenase by annexin 7. Previously, we have shown that following Plasmodium berghei infection, $\mathrm{PGE}_{2}$ plasma levels were larger in annexin 7-deficient mice than in their wild-type littermates [13]. Suppression of $\mathrm{PGE}_{2}$ formation would indeed be expected to enhance gastric acid secretion. Surprisingly, the stimulatory effect of dexamethasone on gastric acid secretion fully depends on annexin 7. Moreover, it is fully mimicked by aspirin. In the presence of aspirin, dexamethasone does not stimulate gastric acid secretion further. Thus, annexin 7-dependent inhibition of cyclooxygenase appears to be critically important for the stimulation of gastric acid secretion by glucocorticoids.

Aspirin enhances gastric acid secretion in both genotypes, i.e. mice lacking annexin $7\left(\operatorname{an} x 7^{-/}\right)$and wild type mice $\left(\operatorname{an} x 7^{+/+}\right)$. It is tempting to speculate that basal gastric acid secretion is suppressed by a cyclooxygenase product, such as $\mathrm{PGE}_{2}$, and that dexamethasone stimulates gastric acid secretion by annexin 7- dependent inhibition of cyclooxygenase.

An increase of extracellular $\mathrm{K}^{+}$concentration to $35 \mathrm{mM}$ enhanced gastric acid secretion, which could not be increased further by application of dexamethasone. An increase of extracellular $\mathrm{K}^{+}$concentration should depolarize the cell membranes thus augmenting the $\mathrm{K}^{+}$exit across the apical membrane. Gastric acid secretion critically depends on $\mathrm{K}^{+}$recycling through KCNQ1 channels [47]. Possibly, annexin 7-sensitive cyclooxygenase activity leads to inhibition of KCNQ1 channels.

In theory annexin 7 may influence the regulation of gastric acid secretion by altered release of secretagogues. Moreover, annexin 7 could interfere with signaling stimulating gastric acid secretion. Gastric acid secretion is stimulated by increase of cytosolic $\mathrm{Ca}^{2+}$ activity and cAMP $[43,65,66]$ as well as by phosphoinositide 3 kinase (PI3K)-dependent signaling [67-70].

According to an earlier study [53], the stimulation of gastric acid secretion depends on the serum- and glucocorticoid-inducible kinase (SGK1), which is known to stimulate a variety of epithelial channels and transporters [71]. The difference between SGK1-deficient mice and their littermates was similarly abrogated in the presence of $35 \mathrm{mM} \mathrm{K}^{+}$[53]. Future studies may disclose interactions of SGK1 and annexin 7-dependent signaling in the regulation of gastric acid secretion.

In conclusion, the gastric acid secretion is similar in $a n x 7^{\%}$ mice and in $a n x 7^{+/+}$mice under basal conditions but cannot be upregulated by the glucocorticoid dexamethasone in anx $7 \%$ mice. Aspirin upregulates gastric acid secretion in both, anx $7 \%$ mice and $a n x 7^{+/+}$mice. Thus, Annexin 7-sensitive cyclooxygenase activity contributes to the stimulation of gastric acid secretion by glucocorticoids.

\section{Abbreviations}

BCECF (2',7'-bis-(2-carboxyethyl)-5-(and-6)-carboxyfluorescein, acetoxymethyl este); DMSO (Dimethylsulfoxide); NMDG (N-methyl D- glucamine); HEPES (4-(2-hydroxyethyl)-1piperazineethanesulfonic acid); ATP $4 \beta$ ( $\beta$-subunit of $\mathrm{H}^{+} / \mathrm{K}^{+}$ATPase); Tbp (TATA box binding protein); PDK (phosphoinositide-dependent kinase); PI3K (phosphoionositol 3 kinase).

\section{Conflict of Interests}

All authors of this manuscript declare that they have no conflicts of interests. 


\section{Acknowledgements}

The authors gratefully acknowledge the meticulous preparation of the manuscript by Lejla Subasic and Sari Rübe. This work was supported by grants from the DFG (SFB 773) and Open Access Publishing Fund of Tuebingen University.

\section{References}

1 Camors E, Monceau V, Charlemagne D: Annexins and Ca2+ handling in the heart. Cardiovasc Res 2005;65:793-802.

-2 Gerke V, Moss SE: Annexins: from structure to function. Physiol Rev 2002;82:331-371.

-3 Monastyrskaya K, Babiychuk EB, Hostettler A, Wood P, Grewal T, Draeger A: Plasma membrane-associated annexin A6 reduces Ca2+ entry by stabilizing the cortical actin cytoskeleton. J Biol Chem 2009;284:1722717242.

4 Monastyrskaya K, Babiychuk EB, Draeger A: The annexins: spatial and temporal coordination of signaling events during cellular stress. Cell Mol Life Sci 2009;66:2623-2642.

5 Raynal P, Pollard HB: Annexins: the problem of assessing the biological role for a gene family of multifunctional calcium- and phospholipid-binding proteins. Biochim Biophys Acta 1994;1197:63-93.

-6 Russo-Marie F: Macrophages and the glucocorticoids. J Neuroimmunol 1992;40:281-286.

7 Yoshizaki H, Tanabe S, Arai K, Murakami A, Wada Y, Ohkuchi M, Hashimoto Y, Maki M: Effects of calphobindin II (annexin VI) on procoagulant and anticoagulant activities of cultured endothelial cells. Chem Pharm Bull (Tokyo) 1992;40:1860-1863.

$>8$ Huber R, Romisch J, Paques EP: The crystal and molecular structure of human annexin V, an anticoagulant protein that binds to calcium and membranes. EMBO J 1990;9:3867-3874.

$>$ Drust DS, Creutz CE: Aggregation of chromaffin granules by calpactin at micromolar levels of calcium. Nature 1988;331:88-91.

10 Ali SM, Geisow MJ, Burgoyne RD: A role for calpactin in calcium-dependent exocytosis in adrenal chromaffin cells. Nature 1989;340:313-315.

11 Emans N, Gorvel JP, Walter C, Gerke V, Kellner R, Griffiths G, Gruenberg J: Annexin II is a major component of fusogenic endosomal vesicles. J Cell Biol 1993;120:1357-1369.

12 Glenney JR Jr: Calpactins: calcium-regulated membrane-skeletal proteins. Biochem Soc Trans 1987;15:798800.

13 Lang PA, Kasinathan RS, Brand VB, Duranton C, Lang C, Koka S, Shumilina E, Kempe DS, Tanneur V, Akel A, Lang KS, Foller M, Kun JF, Kremsner PG, Wesselborg S, Laufer S, Clemen CS, Herr C, Noegel AA, Wieder T, Gulbins E, Lang F, Huber SM: Accelerated clearance of Plasmodium-infected erythrocytes in sickle cell trait and annexin-A7 deficiency. Cell Physiol Biochem 2009;24:415-428.

14 Caohuy H, Srivastava M, Pollard HB: Membrane fusion protein synexin (annexin VII) as a Ca ${ }^{2+} / G_{T P}$ sensor in exocytotic secretion. Proc Natl Acad Sci U S A 1996;93:10797-10802.

-15 Clemen CS, Hofmann A, Zamparelli C, Noegel AA: Expression and localisation of annexin VII (synexin) isoforms in differentiating myoblasts. J Muscle Res Cell Motil 1999;20:669-679.

$>16$ Kuijpers GA, Lee G, Pollard HB: Immunolocalization of synexin (annexin VII) in adrenal chromaffin granules and chromaffin cells: evidence for a dynamic role in the secretory process. Cell Tissue Res 1992;269:323-330.

17 Mears D, Zimliki CL, Atwater I, Rojas E, Glassman M, Leighton X, Pollard HB, Srivastava M: The Anx7(+/-) knockout mutation alters electrical and secretory responses to $\mathrm{Ca}^{2+}$-mobilizing agents in pancreatic betacells. Cell Physiol Biochem 2012;29:697-704.

-18 Alfonso P, Canamero M, Fernandez-Carbonie F, Nunez A, Casal JI: Proteome analysis of membrane fractions in colorectal carcinomas by using 2D-DIGE saturation labeling. J Proteome Res 2008;7:4247-4255.

-19 Bredel M, Scholtens DM, Harsh GR, Bredel C, Chandler JP, Renfrow JJ, Yadav AK, Vogel H, Scheck AC, Tibshirani R, Sikic BI: A network model of a cooperative genetic landscape in brain tumors. JAMA 2009;302:261275.

-20 Eisenhofer G, Huynh TT, Elkahloun A, Morris JC, Bratslavsky G, Linehan WM, Zhuang Z, Balgley BM, Lee CS, Mannelli M, Lenders JW, Bornstein SR, Pacak K: Differential expression of the regulated catecholamine secretory pathway in different hereditary forms of pheochromocytoma. Am J Physiol Endocrinol Metab 2008;295:E1223-E1233.

-21 Hsu PI, Huang MS, Chen HC, Hsu PN, Lai TC, Wang JL, Lo GH, Lai KH, Tseng CJ, Hsiao M: The significance of ANXA7 expression and its correlation with poor cellular differentiation and enhanced metastatic potential of gastric cancer. J Surg Oncol 2008;97:609-614. 
22 Shibata H, Suzuki H, Kakiuchi T, Inuzuka T, Yoshida H, Mizuno T, Maki M: Identification of Alix-type and Non-Alix-type ALG-2-binding sites in human phospholipid scramblase 3: differential binding to an alternatively spliced isoform and amino acid-substituted mutants. J Biol Chem 2008;283:9623-9632.

23 Srivastava M, Torosyan Y, Raffeld M, Eidelman O, Pollard HB, Bubendorf L: ANXA7 expression represents hormone-relevant tumor suppression in different cancers. Int J Cancer 2007;121:2628-2636.

24 Sun MZ, Liu S, Tang J, Wang Z, Gong X, Sun C, Greenaway F: Proteomics analysis of two mice hepatocarcinoma ascites syngeneic cell lines with high and low lymph node metastasis rates provide potential protein markers for tumor malignancy attributes to lymphatic metastasis. Proteomics 2009;9:3285-3302.

25 Torosyan Y, Simakova O, Naga S, Mezhevaya K, Leighton X, Diaz J, Huang W, Pollard H, Srivastava M: Annexin-A7 protects normal prostate cells and induces distinct patterns of RB-associated cytotoxicity in androgen-sensitive and -resistant prostate cancer cells. Int J Cancer 2009;125:2528-2539.

26 Torosyan Y, Dobi A, Glasman M, Mezhevaya K, Naga S, Huang W, Paweletz C, Leighton X, Pollard HB, Srivastava M: Role of multi-hnRNP nuclear complex in regulation of tumor suppressor ANXA7 in prostate cancer cells. Oncogene 2010;29:2457-2466.

27 Yadav AK, Renfrow JJ, Scholtens DM, Xie H, Duran GE, Bredel C, Vogel H, Chandler JP, Chakravarti A, Robe PA, Das S, Scheck AC, Kessler JA, Soares MB, Sikic BI, Harsh GR, Bredel M: Monosomy of chromosome 10 associated with dysregulation of epidermal growth factor signaling in glioblastomas. JAMA 2009;302:276289.

28 Caterino M, Ruoppolo M, Orru S, Savoia M, Perrotta S, Del Vecchio L, Salvatore F, Stewart GW, Iolascon A: Characterization of red cell membrane proteins as a function of red cell density: annexin VII in different forms of hereditary spherocytosis. FEBS Lett 2006;580:6527-6532.

29 Urashima T, Zhao M, Wagner R, Fajardo G, Farahani S, Quertermous T, Bernstein D: Molecular and physiological characterization of RV remodeling in a murine model of pulmonary stenosis. Am J Physiol Heart Circ Physiol 2008;295:H1351-H1368.

-30 Probst-Cousin S, Berghoff C, Neundorfer B, Heuss D: Annexin expression in inflammatory myopathies. Muscle Nerve 2004;30:102-110.

-31 Srivastava M, Atwater I, Glasman M, Leighton X, Goping G, Caohuy H, Miller G, Pichel J, Westphal H, Mears D, Rojas E, Pollard HB: Defects in inositol 1,4,5-trisphosphate receptor expression, $\mathrm{Ca}^{2+}$ signaling, and insulin secretion in the anx7(+/-) knockout mouse. Proc Natl Acad Sci U S A 1999;96:13783-13788.

-32 Herr C, Smyth N, Ullrich S, Yun F, Sasse P, Hescheler J, Fleischmann B, Lasek K, Brixius K, Schwinger RH, Fassler R, Schroder R, Noegel AA: Loss of annexin A7 leads to alterations in frequency-induced shortening of isolated murine cardiomyocytes. Mol Cell Biol 2001;21:4119-4128.

-33 Schrickel JW, Brixius K, Herr C, Clemen CS, Sasse P, Reetz K, Grohe C, Meyer R, Tiemann K, Schroder R, Bloch W, Nickenig G, Fleischmann BK, Noegel AA, Schwinger RH, Lewalter T: Enhanced heterogeneity of myocardial conduction and severe cardiac electrical instability in annexin A7-deficient mice. Cardiovasc Res 2007;76:257-268.

34 Clemen CS, Herr C, Hovelmeyer N, Noegel AA: The lack of annexin A7 affects functions of primary astrocytes. Exp Cell Res 2003;291:406-414.

35 Lang E, Lang PA, Shumilina E, Qadri SM, Kucherenko Y, Kempe DS, Foller M, Capasso A, Wieder T, Gulbins E, Clemen CS, Herr C, Noegel AA, Huber SM, Lang F: Enhanced eryptosis of erythrocytes from gene-targeted mice lacking annexin A7. Pflugers Arch 2010;460:667-676.

-36 Herr C, Clemen CS, Lehnert G, Kutschkow R, Picker SM, Gathof BS, Zamparelli C, Schleicher M, Noegel AA: Function, expression and localization of annexin A7 in platelets and red blood cells: insights derived from an annexin A7 mutant mouse. BMC Biochem 2003;4:8.

-37 Hojgaard L, Mertz NA, Rune SJ: Peptic ulcer pathophysiology: acid, bicarbonate, and mucosal function. Scand J Gastroenterol Suppl 1996;216:10-15.

-38 Konturek SJ, Konturek PC, Brzozowski T: Prostaglandins and ulcer healing. J Physiol Pharmacol 2005;56 Suppl 5:5-31.

39 Sekiguchi F, Takaoka K, Kawabata A: Proteinase-activated receptors in the gastrointestinal system: a functional linkage to prostanoids. Inflammopharmacology 2007;15:246-251.

-40 Hofer AM, Machen TE: K-induced alkalinization in all cell types of rabbit gastric glands: a novel K/H exchange mechanism. J Membr Biol 1992;126:245-256.

41 Hou W, Schubert ML: Gastric secretion. Curr Opin Gastroenterol 2006;22:593-598.

42 Lee HC, Breitbart H, Berman M, Forte JG: Potassium-stimulated ATPase activity and hydrogen transport in gastric microsomal vesicles. Biochim Biophys Acta 1979;553:107-131.

43 Yao X, Forte JG: Cell biology of acid secretion by the parietal cell. Annu Rev Physiol 2003;65:103-131.

44 Dedek K, Waldegger S: Colocalization of KCNQ1/KCNE channel subunits in the mouse gastrointestinal tract. Pflugers Arch 2001;442:896-902. 
45 Heitzmann D, Grahammer F, von Hahn T, Schmitt-Graff A, Romeo E, Nitschke R, Gerlach U, Lang HJ, Verrey F, Barhanin J, Warth R: Heteromeric KCNE2/KCNQ1 potassium channels in the luminal membrane of gastric parietal cells. J Physiol 2004;561:547-557.

-46 Heitzmann D, Koren V, Wagner M, Sterner C, Reichold M, Tegtmeier I, Volk T, Warth R: KCNE beta subunits determine pH sensitivity of KCNQ1 potassium channels. Cell Physiol Biochem 2007;19:21-32.

47 Vallon V, Grahammer F, Volkl H, Sandu CD, Richter K, Rexhepaj R, Gerlach U, Rong Q, Pfeifer K, Lang F: KCNQ1-dependent transport in renal and gastrointestinal epithelia. Proc Natl Acad Sci U S A 2005;102:1786417869.

48 Dong MQ Lau CP, Gao Z, Tseng GN, Li GR: Characterization of recombinant human cardiac KCNQ1/KCNE1 channels (I (Ks)) stably expressed in HEK 293 cells. J Membr Biol 2006;210:183-192.

49 Kurokawa J, Chen L, Kass RS: Requirement of subunit expression for cAMP-mediated regulation of a heart potassium channel. Proc Natl Acad Sci U S A 2003;100:2122-2127.

-50 Marx SO, Kurokawa J, Reiken S, Motoike H, D'Armiento J, Marks AR, Kass RS: Requirement of a macromolecular signaling complex for beta adrenergic receptor modulation of the KCNQ1-KCNE1 potassium channel. Science 2002;295:496-499.

51 Potet F, Scott JD, Mohammad-Panah R, Escande D, Baro I: AKAP proteins anchor cAMP-dependent protein kinase to KvLQT1/IsK channel complex. Am J Physiol Heart Circ Physiol 2001;280:H2038-H2045.

52 Ammar DA, Zhou R, Forte JG, Yao X: Syntaxin 3 is required for cAMP-induced acid secretion: streptolysin O-permeabilized gastric gland model. Am J Physiol Gastrointest Liver Physiol 2002;282:G23-G33.

53 Sandu C, Artunc F, Grahammer F, Rotte A, Boini KM, Friedrich B, Sandulache D, Metzger M, Just L, Mack A, Skutella T, Rexhepaj R, Risler T, Wulff P, Kuhl D, Lang F: Role of the serum and glucocorticoid inducible kinase SGK1 in glucocorticoid stimulation of gastric acid secretion. Pflugers Arch 2007;455:493-503.

54 Rotte A, Pasham V, Mack AF, Bhandaru M, Qadri SM, Eichenmuller M, Ruth P, Lang F: $\mathrm{Ca}^{2+}$ activated $\mathrm{K}^{+}$channel Kca3.1 as a determinant of gastric acid secretion. Cell Physiol Biochem 2011;27:597-604.

55 Rotte A, Pasham V, Bhandaru M, Bobbala D, Zelenak C, Lang F: Rapamycin sensitive ROS formation and $\mathrm{Na}^{+}$/ $\mathrm{H}^{+}$exchanger activity in dendritic cells. Cell Physiol Biochem 2012;29:543-550.

56 Waisbren SJ, Geibel J, Boron WF, Modlin IM: Luminal perfusion of isolated gastric glands. Am J Physiol 1994;266:C1013-C1027.

57 Rotte A, Pasham V, Eichenmuller M, Yang W, Bhandaru M, Lang F: Influence of dexamethasone on $\mathrm{Na}^{+} / \mathrm{H}^{+}$ exchanger activity in dendritic cells. Cell Physiol Biochem 2011;28:305-314.

58 Roos A, Boron WF: Intracellular pH. Physiol Rev 1981;61:296-434.

59 Yang W, Bhandaru M, Pasham V, Bobbala D, Zelenak C, Jilani K, Rotte A, Lang F: Effect of thymoquinone on cytosolic $\mathrm{pH}$ and $\mathrm{Na}+\mathrm{H}+$ exchanger activity in mouse dendritic cells. Cell Physiol Biochem 2012;29:21-30.

60 Boyarsky G, Ganz MB, Sterzel RB, Boron WF: pH regulation in single glomerular mesangial cells. I. Acid extrusion in absence and presence of $\mathrm{HCO}_{3}$. Am J Physiol 1988;255:C844-C856.

61 Bhandaru M, Pasham V, Yang W, Bobbala D, Rotte A, Lang F: Effect of azathioprine on $\mathrm{Na}^{+} / \mathrm{H}^{+}$exchanger activity in dendritic cells. Cell Physiol Biochem 2012;29:533-542.

62 Gawenis LR, Greeb JM, Prasad V, Grisham C, Sanford LP, Doetschman T, Andringa A, Miller ML, Shull GE: Impaired gastric acid secretion in mice with a targeted disruption of the NHE4 $\mathrm{Na}^{+} / \mathrm{H}^{+}$exchanger. J Biol Chem 2005;280:12781-12789.

63 Sidani S, Kopic S, Socrates T, Kirchhoff P, Foller M, Murek M, Capasso A, Geibel JP: AMP-activated protein kinase: a physiological off switch for murine gastric acid secretion. Pflugers Arch 2009;459:39-46.

-64 Sidani SM, Kirchhoff P, Socrates T, Stelter L, Ferreira E, Caputo C, Roberts KE, Bell RL, Egan ME, Geibel JP: DeltaF508 mutation results in impaired gastric acid secretion. J Biol Chem 2007;282:6068-6074.

65 Kopic S, Corradini S, Sidani S, Murek M, Vardanyan A, Foller M, Ritter M, Geibel JP: Ethanol inhibits gastric acid secretion in rats through increased AMP-kinase activity. Cell Physiol Biochem 2010;25:195-202.

66 Schubert ML: Gastric exocrine and endocrine secretion. Curr Opin Gastroenterol 2009;25:529-536.

67 Lang PA, Schniepp R, Kirchhoff P, Socrates T, Sidani SM, Geibel JP: PI3 kinase dependent stimulation of gastric acid secretion by dexamethasone. Cell Physiol Biochem 2007;20:527-534.

68 Rotte A, Bhandaru M, Foller M, Biswas R, Mack AF, Friedrich B, Rexhepaj R, Nasir O, Ackermann TF, Boini KM, Kunzelmann K, Behrens J, Lang F: APC sensitive gastric acid secretion. Cell Physiol Biochem 2009;23:133-142.

69 Rotte A, Mack AF, Bhandaru M, Kempe DS, Beier N, Scholz W, Dicks E, Potzsch S, Kuhl D, Lang F: Pioglitazone induced gastric acid secretion. Cell Physiol Biochem 2009;24:193-200.

70 Rotte A, Pasham V, Bhandaru M, Eichenmuller M, Yang W, Qadri SM, Kempe DS, Puchchakayala G, Pearce D, Birnbaum MJ, Lang F: Regulation of gastric acid secretion by PKB/Akt2. Cell Physiol Biochem 2010;25:695704.

71 Lang F, Bohmer C, Palmada M, Seebohm G, Strutz-Seebohm N, Vallon V: (Patho)physiological significance of the serum- and glucocorticoid-inducible kinase isoforms. Physiol Rev 2006;86:1151-1178. 